\title{
PENGGUNAAN TEKNIK TIME TOKEN ARENDS PADA METODE DEBAT UNTUK MENINGKATKAN KEMAMPUAN MEMPROSES INFORMASI SISWA DALAM PEMBELAJARAN SEJARAH
}

\author{
Oleh: \\ Ayu Oktapiani, Murdiyah Winarti ${ }^{1}$
}

\begin{abstract}
The article entitled Time Token Arends Implementation in the Debate Method to Improve the Student Information Processing Skill in History Study. The background of this research was the lack of students' information processing skill, where students often had difficulties on remembering the material easily, the lack of distribution and participation in communicating their opinion and argument as the result of information processing and becomes the characteristic of the passive class. The purpose of this study is to improve students' information processing skill. Began with the identification, implementation, improvement and obstacles during the conducted of this research and the effort that implemented to resolve those obstacles. The research design used Kemmis and Mc. Taggart classroom action research model. Data collection that used is observation, interview and documentation study. Data collection tools or research instrument that used field note, teacher and student guidance observation paper and interview guidance. This research consists of three cycles and three actions. The observation result of each cycle that increased significantly from the first cycle until the third cycle. Some of the recommendation to the teacher, school, other researchers and History Education Department, which are the facilities optimization and communication tools in school.
\end{abstract}

Keywords: Debate Method, Information Processing Skill, Time Token Arends Technique

\section{PENDAHULUAN}

Sekolah merupakan lembaga pendidikan dan wadah pembentukan pribadi siswa ke arah yang lebih baik. Pembentukan pribadi siswa mencakup perkembangan dalam aspek fisik, mental dan intelektual. Perkembangan tersebut dalam rangka mempersiapkan sumber daya manusia yang siap menghadapi kompetisi di dunia kerja. Dalam hal ini sekolah sebagai sarana membentuk lulusan yang berkualitas dan memiliki kompetensi yang memadai untuk kariernya pada masa yang akan datang (Rusman, 2015, hlm. 87). Sejarah merupakan salah satu mata pelajaran dalam ranah ilmu pengetahuan sosial yang dinilai sangat penting dan memiliki pengaruh yang besar dalam kurikulum 2013. Pembelajaran sejarah di sekolah sebagian besar dilaksanakan

${ }^{1}$ Ayu Oktapiani adalah mahasiswa Departemen Pendidikan Sejarah FPIPS UPI. Murdiyah Winarti adalah Dosen Pembimbing. Penulis dapat dihubungi pada email: ayytetaishi@ gmail.com. 
dengan situasi yang kurang menyenangkan (Garvey, 2015, hlm. 18). Penataan ruang kelas tradisional menciptakan interaksi yang kaku antara guru dengan murid. Salah satu tantangan besar yang dihadapi oleh guru sejarah yaitu memperbaiki interaksi yang kaku dan tradisional dan mampu mengembangkan pemahaman siswa tentang masa lalu melalui halhal yang siswa lihat di masa kini yang kadang bukanlah menjadi sesuatu yang menyenangkan.

Begitupun dengan kondisi pembelajaran Sejarah di kelas XI MIPA 1 SMA Negeri 1 Cisarua. Siswa merasa bosan dan kejenuhan selama pembelajaran Sejarah berlangsung. Karena siswa yang menganggap sejarah adalah pembelajaran yang berputar tentang masa lalu yang bersifat menghapal fakta-fakta saja tanpa adanya sesuatu hal lainnya yang menarik untuk dipelajari. Hal tersebut dapat mempengaruhi penguasaan materi dan pemprosesan informasi serta pemahaman siswa. Meskipun perfoma guru dalam melaksanakan pembelajaran Sejarah di kelas XI MIPA 1 sudah sangat baik akan tetapi pemanfaatan sarana, sumber, metode dan teknik yang dirasa kurang tepat dan sama tiap tahunnya yang menjadikan pembelajaran sejarah menjadi mata pembelajaran yang kurang menarik. Sesuai dengan pendapat Garvey (2015, hlm. 18) yang mengatakan bahwa "jika kondisi kelas tetap sama tiap tahunnya dan metode serta teknik pembelajaran yang diterapkan kurang tepat dan kurang bervariasi maka cara belajar yang diterapkan akan terasa membosankan". Karena pada dasarnya Sejarah merupakan pembelajaran yang tidak bisa lepas dari fakta, ruang dan waktu dengan kemampuan dasar yang harus dilakukan siswa adalah mengingat dan menghapal.

Ketika siswa yang lain memperhatikan apa yang guru jelaskan, terdapat beberapa siswa yang memilih untuk melakukan hal-hal yang menurut mereka lebih menyenangkan seperti tidur atau main gadget sambil mengobrol dengan teman sebangku bahkan ada yang tertidur. Guru pun sudah mengingatkan dengan berbagai cara mulai dari menegur secara langsung sampai memberikan pertanyaan dengan tujuan agar siswa kembali fokus pada materi pembelajaran. Mobilitas guru pun selama pembelajaran di kelas berlangsung secara tinggi dan baik. Di mulai dari depan ke tengah sampai berkeliling untuk memperhatikan apa yang sedang siswa lakukan.

Kemudian, ketika guru di kelas XI MIPA 1 mengajukan pertanyaan, siswa yang menanggapi pertanyaan guru dan aktif di kelas hanya itu-itu saja. Sedangkan siswa yang lainnya hanya diam saja. Saat guru memberikan intruksi kepada siswa untuk melakukan kegiatan diskusi kelompok untuk menggali lebih jauh terkait materi yang disampaikan, yang bekerja dalam kelompok pun hanya sebatas satu sampai dua orang yang benar-benar melakukan aktivitas memproses informasi dalam kelompok. Beberapanya hanya melihat pekerjaan teman sekelompoknya sambil mengobrol dan bercanda. Kemudian, selama kegiatan presentasi berlangsung, siswa lain yang menjadi pendengar sibuk dengan kegiatan masing-masing seperti bermain games, mengobrol dengan teman sebangku dan bahkan terliat beberapa yang secara terang-terangan tertidur, hingga suasana kelas saat presentasi berlangsung sangat pasif. Guru pun sudah berusaha 
untuk menegur siswa-siswa tersebut dan itu hanya berlangsung sampai 15 menit saja. Ketika sesi tanya jawab dibuka yang terjadi adalah pertanyaan yang diajukan oleh siswa bersifat kewajiban saja yaitu untuk menambah nilai dengan meminta pertanyaan dari teman yang menurut siswa tersebut pintar dan dapat diandalkan bukan pertanyaan yang benar-benar karena ingin mengeksplor lebih mendalam. Siswa yang menjawab pertanyaan dalam kelompok presentator pun hanya satu atau dua orang yang dominan karena teman kelompok yang lainnya hanya diam saja tidak memberikan jawaban atau pun argumennya.

Penelitian tindakan kelas memiliki fungsi yaitu untuk melakukan perubahan agar terjadi peningkatan ke arah yang lebih baik dalam proses pembelajaran maupun hasil belajar. Penelitian ini dilakukan setelah peneliti melakukan pengamatan sebagai observer di sekolah SMAN 1 Cisarua khususnya di kelas XI MIPA 1 dan melakukan wawancara kepada beberapa siswa serta wawancara dengan guru yang bersangkutan. Pengamatan ini dimaksudkan untuk mengidentifikasi permasalahan selama proses pembelajaran sehingga dapat melakukan perbaikanperbaikan yang dibutuhkan siswa selama proses pembelajaran dan berimbas pada hasil belajar. Berdasarkan hasil pengamatan permasalahan pembelajaran di kelas yang sudah dijelaskan di atas, diskusi dan curah pendapat ditemukan bahwa di sekolah SMAN 1 Cisarua kelas XI MIPA 1 dalam mata pelajaran sejarah terdapat masalah yang dinilai sangat urgent diantara yaitu: pertama, siswa acapkali cepat lupa dengan materi sejarah yang sudah mereka pelajari sebelumnya karena siswa menganggap sejarah hanya bersifat menghapal saja. Kedua, metode dan teknik yang digunakan tiap tahunnya sama dan selama pembelajaran dirasa kurang menarik minat siswa sehingga siswa di kelas menjadi pasif. Ketiga, rendahnya partisipasi siswa dalam hal menanggapi atau berpendapat. Keempat, rendahnya komunikasi siswa sebagai hasil dari mengolah informasi. Kelima, rendahnya pendistribusian partisipasi siswa dalam memproses informasi karena setiap siswa dalam kelompok hanya mengandalkan satu atau dua siswa saja.

Berdasarkan permasalahan pembelajaran Sejarah tersebut, guru mitra dan peneliti pun kemudian sepakat untuk mengubah teknik pembelajaran Sejarah. Upaya perbaikan yang dirasa dapat mengatasi permasalahan siswa di kelas XI MIPA 1 SMAN 1 Cisarua yaitu dengan mengunakan teknik pembelajaran Time token Arends pada metode debat untuk meningkatkan kemampuan memproses informasi siswa.

Teknik time token Arends dinilai dapat membantu mendistribusikan partisipasi memproses informasi siswa lebih merata dengan mengurangi beberapa siswa yang dominasi pembicaraan dan beberapa siswa yang pemalu atau diam sama sekali (Arends, 2008, hlm. 138). Karena pada dasarnya untuk melihat kemampuan memproses informasi siswa dapat dilakukan dengan cara mengomunikasikan apa yang ada dalam pemikirannya sebagai hasil dari pengolahan informasi.

Pertimbangan peneliti memilih teknik time token Arends pada metode debat berdasarkan pada rendahnya pendistribusian partisipasi dalam mengolah informasi karena setiap kelompok diskusi dan belajar hanya 
mengandalkan satu atau dua siswa saja yang aktif mengomunikasikan pendapat, ide dan gagasannya. Siswa yang lainnya hanya mendengarkan, malu-malu bahkan diam sama sekali tanpa adanya partisipasi aktif di kelas, yang kemudian menjadikan situasi kelas XI MIPA 1 ini menjadi kelas pasif.

Teknik time token arends ini memberikan kesempatan kepada siswa yang merasa kurang percaya diri dan selalu merasa malu atau diam untuk mengungkapkan pemikirannya yang mereka dapatkan yang kemudian informasi tersebut mereka olah yang selanjtnya bisa mereka komunikasikan sebagai bentuk hasil dari pengolahan informasi dalam bentuk argumen, pendapat atau pun pertanyaan-pertanyaan yang dikemas pada situasi debat dengan memperhatikan time token atau tanda waktu (batasan waktu) siswa dalam mengomunikasikan pendapat, argumen atau pertanyaanpertanyaan yang diajukan lebih terarah. Hal ini diperkuat dengan pendapat dari Purnomo (2014, hlm. 2) yang mengatakan bahwa "pemahaman yang dimiliki oleh siswa sangat dipengaruhi oleh informasi yang ada pada diri siswa itu sendiri berkaitan dengan informasi yang telah mereka proses”. Sehingga teknik time token arends pada metode debat ini dinilai dapat lebih mempertajam kemampuan memproses informasi siswa dan meratakan pendistribusian partisipasi kemampuan siswa dalam memproses informasi. Partisipasi siswa dalam memproses informasi ini dapat dilihat dari indikator yang tidak tampak di satu siswa saja melainkan mendistribusikan indikator partisipasi memproses informasi yang akan merata.
Kemampuan memproses infromasi adalah tujuan pembelajaran yang belum banyak disinggung dalam pendidikan ranah ilmu pengetahuan sosial khususnya Sejarah bahkan muncul kesan pembelajaran ilmu sosial kurang memperhatikan kemampuan ini. Pada hakikatnya kemampuan memproses informasi merupakan kemampuan yang sangat penting untuk dikembangkan dalam pendidikan ilmu-ilmu sosial (Hasan, 1997, hlm. 214). Melihat hal tersebut dan permasalahan yang ditemukan di kelas XI MIPA 1 selama peneliti menjadi observer di kelas dan curah pendapat dengan guru mitra. Peneliti pun memutuskan untuk melakukan penelitian dan mengambiljudul "Penggunaan Teknik Time Token Arends pada Metode Debat untuk meningkatkan Kemampuan Memproses Informasi Siswa dalam Pembelajaran Sejarah (Penelitian Tindakan Kelas di Kelas XI MIPA 1 SMA Negeri 1 Cisarua)”.

Berdasarkan latar belakang masalah penelitian di atas, rumusan masalah utama dalam penelitian ini yaitu "Bagaimana Penggunaan Teknik Time Token Arends pada Metode Debat untuk Meningkatkan Kemampuan Memproses Informasi Siswa dalam Pembelajaran Sejarah di kelas XI MIPA 1 SMA Negeri 1 Cisarua?”

\section{METODE PENELITIAN}

Metode penelitian penggunaan teknik time token arends pada metode debat untuk meningkatkan kemampuan memproses informasi siswa dalam pembelajaran sejarah menggunakan Penelitian Tindakan Kelas (PTK). Penelitian tindakan kelas menurut Stringer (dalam Mulyasa, 2009, hlm. 151) mengartikan penelitian tindakan kelas sebagai "disciplined 
inquiry (research) which seeks focused efforts to improve the quality of people's organization, community and family lived". Sedangkan menurut Kemmis (dalam Wiriaatmadja, 2012, hlm. 12) adalah "sebuah bentuk inkuiri refleksi yang dilakukan secara kemitraan mengenai situasi sosial tertentu (termasuk pendidikan) untuk meningkatkan rasional dan keadilan dari kegiatan praktek sosial dan pendidikan, pemahaman mengenai praktek pendidikan dan situasi yang mendukung terlaksananya praktek pendidikan ini”. Kemudian, menurut Arikunto, dkk (2009) penelitian tindakan kelas merupakan "suatu pencermatan terhadap kegiatan belajar berupa sebuah tindakan yang sengaja dimunculkan dan terjadi dalam kelas secara bersamaan dengan arahan dari guru yang dilakukan oleh siswa”.

Pendapat di atas menunjukan bahwa penelitian tindakan kelas merupakan upaya yang ditunjukan untuk memperbaiki keadaaan (proses kerja) atau memecahkan masalah yang dihadapi dengan mencari kebeneran secara praktis. Secara sederhana penelitian tindakan kelas adalah bagaimana guru dapat mengorganisasikan kondisi pembelajaran siswa guna mencobakan perbaikan pembelajaran dan melihat kepengaruhan dari upaya tersebut.

Ada beberapa karakteristik penelitian tindakan kelas yang membedakannya dengan penelitian lainnya (Sukardi, 2013, hlm. 20), yaitu: Pertama, permasalahan yang dipecahkan merupakan persoalan praktis yang dihadapi peneliti dalam kehidupan profesi sehari-hari. Kedua, peneliti memberikan perlakuan atau melakukan tindakan (treatment) berupa tindakan terencana untuk memecahkan permasalahan, sekaligus meningkatkan kualitas yang dapat dirasakan implikasinya oleh subjek yang diteliti. Ketiga, langkahlangkah penelitian yang direncanakan selalu dalam bentuk siklus, tingkatan atau daur yang memungkinkan terjadinya peningkatan perbaikan dalam setiap siklusnya. Keempat, adanya langkah berpikir reflektif (reflective thinking) yang dilakukan oleh para peneliti baik sesudah maupun sebelum tindakan dilakukan. Kelima, penelitian dilakukan secara kolaboratif yaitu oleh dua orang atau lebih. Keenam, peneliti menangkap fenomena yang muncul lalu menggunakannya sebagai data atau informasi penelitian.

Pemilihan teknik pembelajaran ini didasarkan atas penemuan masalah di lapangan sebagai hasil diagnostik dari pra penelitian yang telah dilakukan sebelumnya. Adapun permasalahan utama yang peneliti temukan, yaitu rendahnya keterampilan memproses informasi siswa terutama dalam hal menanggapi atau berpendapat dengan kondisi siswa yang hanya diam tidak menanggapi pertanyaan yang diajukan guru. Siswa yang menanggapi pertanyaan guru hanya satu sampai dua orang dan hanya itu-itu saja. Kedudukan peneliti selama melakukan penelitian dapat menjadi guru ataupun observer. Hal ini berguna agar penelitian tindakan kelas ini menjadi lebih baik sesuai siklusnya dan merasakan langsung kendala-kendala apa saja yang dihadapi selama proses penerapan teknik time token arends pada metode debat untuk meningkatkan keterampilan memproses informasi siswa dalam pembelajaran sejarah dan dapat mencari solusi untuk kendala-kendala yang dihadapi.

Desain tindakan yang digunakan dalam penelitian tindakan kelas ini mengacu pada model penelitian tindakan 
kelas Kemmis dan Mc. Taggart yang terdiri dari empat tahapan, yaitu perencanaan (planning), pelaksanaan tindakan (action), pengamatan (observation), dan refleksi (reflect).

Desain penelitian tindakan kelas model spiral dari Kemmis dan Mc. Taggrat ini dipilih karena alur dan langkah-langkah yang dilakukan dalam penelitian model spiral ini sangat praktis dan sistematis yang diharapkan dapat mempermudah penelitian yang akan dilakukan oleh peneliti. Penelitian tindakan kelas ini dilakukan dengan pola siklus. Pada setiap akan siklus diamati atau dilihat peningkatan yang diperoleh siswa. Apabila belum terjadi perubahan atau peningkatan, penelitian akan dilanjutkan pada siklus selanjutnya, dengan memperhatikan refleksi dan pembertimbangkan kendalakendala yang memperngaruhi siklus sebelumnya sehingga ditemukan solusi atau upaya dalam menangani kendala selama siklus sebelumnya. Apabila sudah terjadi perubahan maka penelitian dapat dicukupkan pada siklus tersebut.

\section{HASIL PENELITIAN DAN PEMBAHASAN}

Berdasarkan pada hasil penelitian temuan di lapangan setelah diterapkannya teknik time token Arends pada metode debat untuk meningkatkan kemampuan memproses informasi siswa, diperoleh hasil bahwa kemampuan memproses informasi siswa mengalami peningkatan pada tiap tindakannya. Di bawah ini adalah tabel perolehan skor siswa disetiap tindakannya terhadap indikator kemampuan memperoses informasi siswa dalam pembelajaran sejarah dengan menggunakan teknik time token Arends pada metode debat.

Tabel 9.1

Perolehan Skor Per-Individu

\begin{tabular}{|l|l|l|l|l|}
\hline \multirow{2}{*}{ No. } & \multirow{2}{*}{ Nama Siswa } & \multicolumn{3}{|c|}{ Perolehan Skor } \\
\cline { 3 - 5 } & & Tindakan I & Tindakan II & Tindakan III \\
\hline 1. & A & 6 & - & 13 \\
\hline 2 & ANS & 7 & 10 & 15 \\
\hline 3 & AMS & 9 & 12 & 15 \\
\hline 4 & APA & 7 & 12 & 15 \\
\hline 5 & AN & 7 & 10 & 14 \\
\hline 6 & ASM & - & 4 & - \\
\hline 7 & AKW & 7 & 8 & - \\
\hline 8 & AF & 7 & 13 & 14 \\
\hline 9 & CS & 7 & 10 & 15 \\
\hline 10 & DRR & 9 & 4 & - \\
\hline 11 & DE & 6 & 13 & - \\
\hline 12 & DW & 9 & 14 & 15 \\
\hline 13 & DI & 11 & 13 & 14 \\
\hline
\end{tabular}




\begin{tabular}{|c|c|c|c|c|}
\hline 14 & FNR & 9 & 4 & 15 \\
\hline 15 & FMD & 3 & 4 & - \\
\hline 16 & GA & - & 10 & 14 \\
\hline 17 & GSP & - & 7 & 14 \\
\hline 18 & HSA & 7 & 10 & 14 \\
\hline 19 & IFK & 2 & - & - \\
\hline 20 & IAH & 3 & 8 & 8 \\
\hline 21 & KK & 4 & 6 & 14 \\
\hline 22 & KLM & 7 & - & 15 \\
\hline 23 & MPN & 7 & 13 & 15 \\
\hline 24 & MYP & 3 & 8 & 8 \\
\hline 25 & MD & 4 & 8 & 13 \\
\hline 26 & RSN & 3 & 14 & 15 \\
\hline 27 & RRD & 7 & 9 & 13 \\
\hline 28 & RDN & 8 & 14 & 14 \\
\hline 29 & RPA & 8 & 8 & 14 \\
\hline 30 & RR & 8 & 4 & 14 \\
\hline 31 & RF & 9 & 15 & - \\
\hline 32 & RAB & 5 & 7 & 14 \\
\hline 33 & SDM & 7 & 12 & 15 \\
\hline 34 & SAS & 8 & 10 & 15 \\
\hline 35 & TL & 10 & 10 & 15 \\
\hline 36 & TJF & 2 & - & - \\
\hline 37 & YTR & - & 12 & - \\
\hline 38 & ZS & 8 & 10 & 13 \\
\hline \multicolumn{2}{|c|}{ Jumlah Skor } & 224 & 326 & 402 \\
\hline \multicolumn{2}{|c|}{ Jumlah Skor Maksimal } & \multicolumn{3}{|c|}{608} \\
\hline \multicolumn{2}{|c|}{ Rata-Rata Nilai } & 36,8 & 53,6 & 66,1 \\
\hline
\end{tabular}

Berdasarkan tabel di atas, dapat dilihat bahwa pada siklus ke-I prosentase rata-rata yang diperoleh adalah $36,8 \%$ dengan kriteria "Cukup". Selanjutnya pada siklus ke-II mulai terlihat adanya peningkatan walaupun yang cukup signifikan dengan prosentase rata-rata adalah 53,6\% dengan kriteria "Cukup". Kemudian pada siklus ke-III prosentase rata-rata kembali mengalami peningkatan dengan prosentase rata-rata sebesar $66,1 \%$ dengan kriteria "Baik". Selanjutnya data hasil observasi setiap siklus di atas akan ditampilkan dalam bentuk diagram batang sebagai berikut: 


\section{Grafik 9.1}

\section{Hasil Seluruh Tindakan untuk Penilaian Individu}

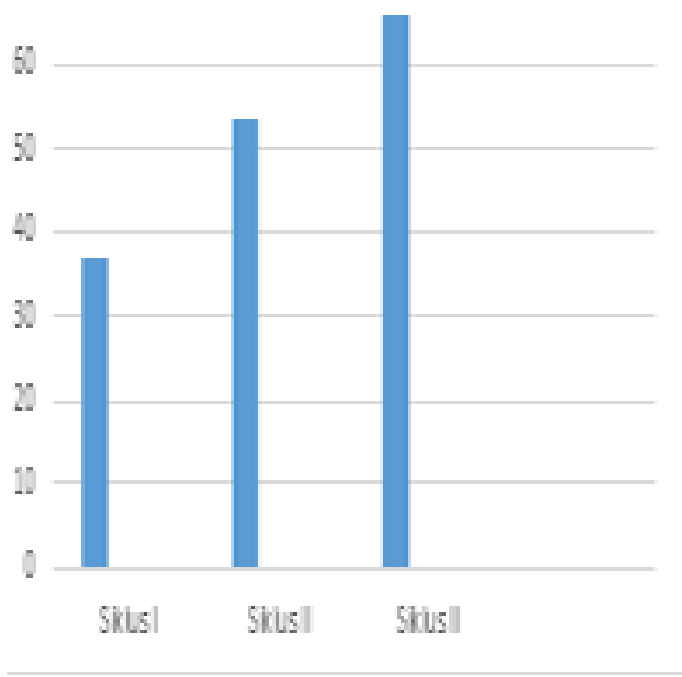

Berdasarkan diagram tersebut dapat dilihat bahwa penggunaan teknik time token Arends pada metode debat untuk meningkatkan kemampuan memproses informasi siswa dapat berjalan dengan baik dan adanya peningkatan selama tiga siklus. Hal tersebut dapat dilihat dari hasil pencapaian pada setiap siklusnya. Pada siklus 1 mengalami peningkatan $36,8 \%$, siswa dinyatakan sudah cukup ada kemampuan meperoses informasi, walaupun hanya setengah dari 38 siswa yang ada. Pada siklus II mengalami peningkatan yang signifikan $53,6 \%$, siswa dinyatakan sudah baik dalam kemampuan memproses informasi. Pada siklus III mengalami peningkatan kembali 66,1\%, siswa dinyatakan sudah baik dalam kemampuan memproses informasi denagn jumlah 29 siswa yang hadir.

Terlihat dari peningkatan skor kemampuan berpikir kronologis siswa dengan penggunaan teknik time token arends pada metode debat, maka dapat ditarik kesimpulan bahwa dengan menggunakan teknik time token arends pada metode debat siswa dapat memproses informasi dan tidak mudah luapa peristiwa sejarah. teknik time token Arends pada metode debat mampu mempermudah siswa dalam memahami pembelajaran sejarah dan menjadikan peristiwa sejarah tidak mudah untuk dilupakan atau selalu diingat sehingga menjadi long-term memory.

Data yang diperoleh dari hasil observasi untuk penilaian individu akan dikonversikan ke dalam skor dengan skala interval dan dikonversikan ke dalam bentuk nilai yaitu sangat baik, baik, cukup, dan kurang. Berikut ini akan dipaparkan hasil pengolahan berdasarkan deskripsi siklus I sampai dengan siklus III mengenai penggunaan teknik time token Arends pada metode debat untuk meningkatkan kemampuan memproses informasi siswa dalam pembelajaran sejarah.

Berdasarkan diagram 9.2 dapat dilihat bahwa penggunaan teknik time token Arends pada metode debat untuk meningkatkan kemampuan memproses informasi siswa dapat berjalan dengan baik dan adanya peningkatan secara signifikan selamatiga siklus. Hal tersebut dapat dilihat dari hasil pencapaian pada indikator setiap siklusnya. Pada siklus 1, dari tiga indikator penilaian yang terendah adalah indikator satu, yakni kemampuan mengumpulkan informasi dengan perolehan skor 1 dari 4. Dalam pemantauan observer, hampir semua siswa tidak menggunakan sumber bacaan dan hanya mengandalkan dan mengdengarkan penjelasan dari beberapa siswa yang memang telah mengumpulkan informasi sebelumnya. Pada siklus ke II, 
Tabel 9.2

Hasil Seluruh Tindakan untuk Penilaian Individu

\begin{tabular}{|c|c|c|c|c|}
\hline No & $\begin{array}{l}\text { Indikator Kemampuan Memproses Informasi } \\
\text { Siswa }\end{array}$ & $\underline{\text { Siklus }}$ & $\underline{\text { Siklus }}$ & $\begin{array}{l}\underline{\text { Siklus }} \\
\underline{\text { III }}\end{array}$ \\
\hline$\underline{1}$ & $\begin{array}{l}\text { Mengumpulkan Informasi } \\
\text { - Mencari informasi di berbagai sumber }\end{array}$ & $\underline{1}$ & $\underline{2}$ & 3 \\
\hline$\underline{2}$ & $\begin{array}{l}\text { Mengolah Informasi } \\
\text { - } \quad \text { Melakukan Identifikasi dan Analisis }\end{array}$ & $\underline{2}$ & 3 & 3 \\
\hline 3 & \begin{tabular}{l}
\multicolumn{2}{l}{ Mengomunikasikan Hasil } \\
- $\quad$ Mengungkapkan Pendapat \\
- $\quad$ Penempatan/ketepatan Durasi
\end{tabular} & 4 & $\underline{6}$ & $\underline{8}$ \\
\hline \multicolumn{2}{|r|}{ Jumlah Skor Siklus } & $Z$ & $\underline{11}$ & $\underline{14}$ \\
\hline
\end{tabular}

Grafik 9.2

Hasil Kemampuan Memproses Informasi Siswa

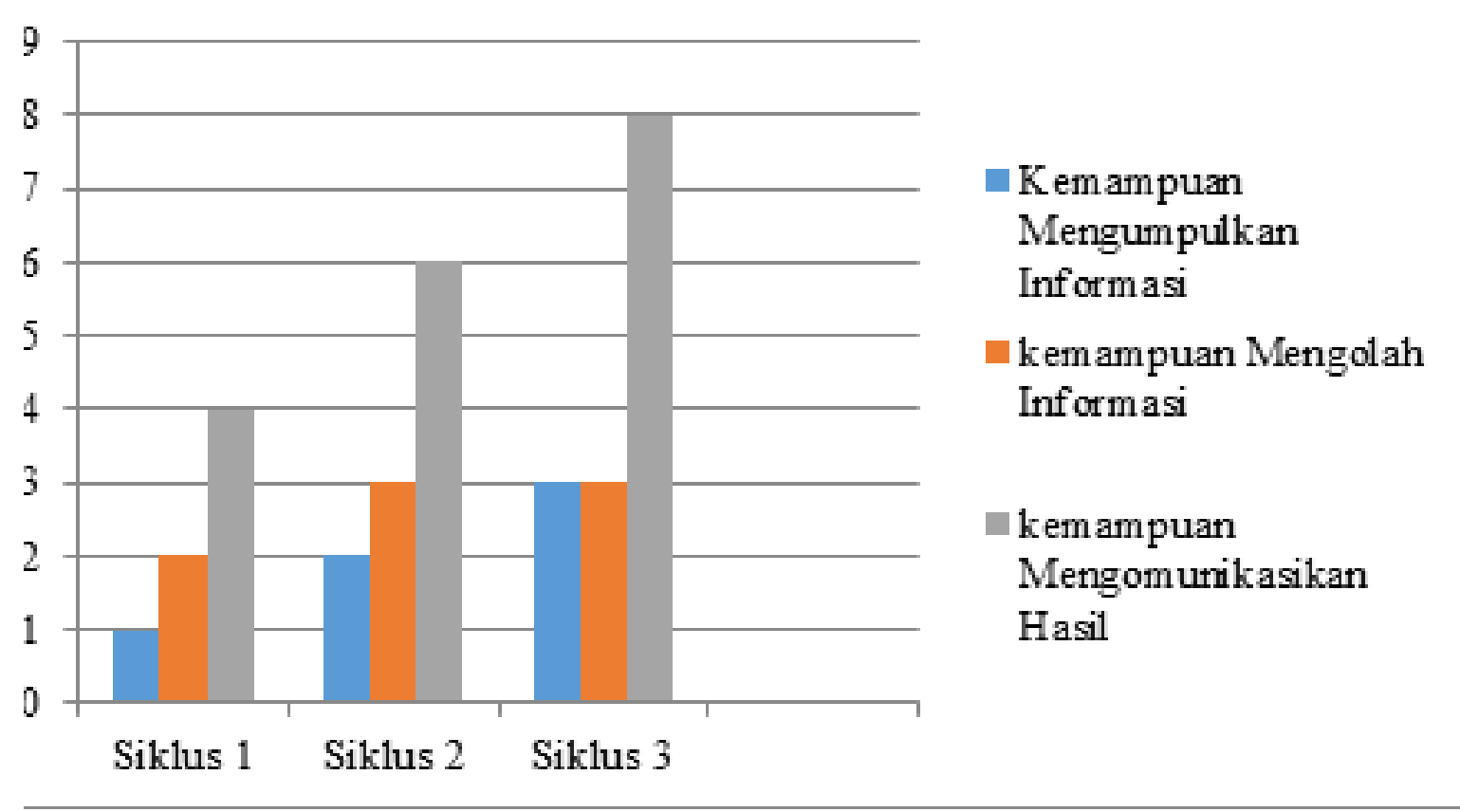

dari tiga indikator penilaian yang paling rendah yaitu kemampuan mengumpulkan informasi dengan perolehan skor 2 dari 4. Indikator pada siklus II ini mengelami peningkatan yaitu dari perolehan skor pada siklus I sebanyak satu meningkat menjadi dua. Dalam pemantauan observer, kebanyakan siswa hanya menggunakan satu sumber bacaan dan beberapa siswa mulai mengalami peningakatan dalam mengumpulkan sumber bacaan ada yang awalnya satu menjadi dua sumber 
bacaan, mereka masih mengandalkan dan mendengarkan penjelasan beberapa siswa yang menggunakan dua atau lebih sumber bacaan. Kemudian, pada siklus ke III, dari tiga indikator yang terendah adalah kemampuan megumpulkan informasi dan mengolah informasi dengan perolehan skor 3 dari 4. Hal ini dikarenakan beberapa siswa masih hanya menggunakan satu sumber dan tidak melakukan kegiatan analisis.

Terlihat dari peningkatan skor kemampuan memproses informasi siswa dengan penggunaan teknik time token arends pada metode debat, maka dapat ditarik kesimpulan bahwa dengan menggunakan teknik time token Arends pada metode debat siswa dapat memproses informasi yang kemudian sangat terlihat jelas melalui cara siswa mengomunikasikan hasil dari mengolah informasi tersebut yang dituangkan dalam pendapatnya berikut alasan-alasan guna memperkuat argumen siswa dengan kalimat efektif sehingga siswa dapat lebih memahami peristiwa sejarah dan tidak mudah lupa akan peristiwa sejarah tersebut yang kemudian tersimpan dalam long-term memory setiap siswa.

Penggunaan tenik time token Arends ini dapat melatih dan mengembangkan keterampilan sosial siswa agar siswa tidak mendominasi pembicaraan atau diam sama sekali karena mereka berkonsentrasi menyimak pembicaraan. Hal tersebut sejalan dengan pendapat Arends (2008, hlm. 138) yang mengatakan bahwa "teknik time token Arends dinilai dapat membantu mendistribusikan partisipasi memproses informasi siswa siswa lebih merata dengan mengurangi beberapa siswa yang dominasi pembicaraan dan beberapa siswa yang pemalu atau diam sama sekali”.
Selama proses perencanaan sampai pada proses pengamatan tindakan pembelajaran Sejarah berlangsung tidak lepas dari adanya kendala-kendala yang dihadapai oleh peneliti sebagai guru dalam melaksanaan penelitian penggunaan teknik time token Arends pada metode debat dalam meningkatkan kemampuan memproses informasi siswa ini. Kendalakendala ini dialami oleh peneliti dan dirasakan pula oleh guru mitra dan observer.

Adapun kendala-kendala yang dihapai dalam penggunaan teknik time token Arends dalam pembelajaran Sejarah, yaitu:

1. Pengembangan pembelajaran di kelas, peneliti mengalami kesulitan dalam hal menentukan isu yang sifatnya kontroversial yang cocok dan sesuai dengan kemampuan kognitif dan kapasitas siswa tingkat sekolah menengah karena siswa sudah terbiasa dengan proses belajar satu arah dengan hanya menyimak materi yang diberikan oleh guru yang kurang dibiasakan untuk bertanya ataupun mengungkap pendapat.

2. Siswa dalam proses diskusi banyak yang tidak berkontribusi dan hanya mengandalkan beberapa siswa yang pintar saja dalam kelompoknya. Di sini peneliti harus berusaha keras agar mereka bekerjasama dalam proses diskusi dan mengutarakan pendapatnya dalam proses diskusi. Keadaan tersebut sesuai dengan pendapat Wina Sanjaya (dalam Bashori, 2017, hlm. 200) katakan tentang kelemahan dari time token Arends yaitu "siswa yang memiliki kelebihan akan merasa terhambat oleh 
siswa yang dianggap kurang memiliki kemampuan". Akibatnya, keadaan semacam ini dapat mengganggu iklim kerja sama dalam kelompok

3. Siswa terbiasa berfokus pada buku paket atau satu sumber saja tanpa berusaha mencari dan menggali di berbagai sumber lainnya. Hal tersebut tidak sejalan dengan kelebihan dari teknik time token yaitu dapat menambah menemukan informasi dari berbagai sumber (dalam Bashori, 2017, hlm. 200). Karena pada dasarnya masih banyak siswa XI MIPA 1 yang secara finansial tidak memenuhi untuk mencari sumber informasi lainnya. Penggunaan alat komunikasi siswa SMA Negeri 1 Cisarua sangat dibatasi khususnya bagi siswa-siswa XI MIPA 1 yang menjalankan proses pendidikan dengan batuan dari provinsi atau siswa asrama.

Berdasarkan pengamatan di lapangan di atas, upaya yang dilakukan oleh guru dalam menghadapi kendala yang terjadi di dalam kelas diantaranya yaitu:

1. Memperbanyak diskusi dengan guru mitra yang lebih memahami kondisi kognitif dan kemampuan siswa XI MIPA 1. Selain itu, peneliti pun melakukan diskusi dan curah pendapat dengan rekan observer sejarah dan guru sejarah kelas XI SMA Negeri 1 Cisarua serta teman-teman pendidikan sejarah lainnya. Kemudian, peneliti dan guru mitra mengidentifikasi kembali isu-isu kontroversial yang akan menjadi topik pada dalam tindakan pembelajaran berikutnya. Isu tersebut diidenifikasi dengan pertimbangan sumber yang tersedia relatif banyak dan mudah diakses oleh siswa XI MIPA 1.
2. Modifikasi aturan main dan memperkuat aturan time token Arends pada metode debat yaitu pada bagian mengungkapkan pendapat. Seperti pada proses pendistribusian kesempatan siswa. Siswa yang belum berkesempatan berbicara atau mengungkapkan pendapatnya didahulukan untuk berbicara pada siklus berikutnya. Sehingga kontribusi siswa-siswa XI MIPA 1 dapat terjadi secara maksimal tanpa dominasi dari siswa tertentu saja.

3. Modifikasi aturan mengumpulkan sumber yang tidak menyulitkan siswa. Siswa diharuskan mencari ke perpustakaan atau dunia maya (internet) dengan menuliskan identitas dari sumber yang digunakan. Buku paket yang digunakan oleh siswa XI MIPA 1 hanya sebagai pendukung saja. Peneliti pun sempat memberikan lembaran bacaan materi yang menunjang untuk proses debat.

4. Upaya untuk mengatasi kendala dari point dua dan tiga selain seperti yang sudah dipaparkan di atas. Peneliti dan guru mitra pun sepakat untuk memperbanyak lembar kerja siswa.

5. Guru berusaha untuk mengeraskan intonasi suara agar dapat terdengar dan mengkondusifkan kelas XI MIPA 1 saat tidak kondusif. Guru melakukan mobilisasi agar dapat menguasai seluruh kelas dan memantau perkembangan kinerja siswa XI MIPA 1 dalam kelompok.

\section{SIMPULAN}

Peningkatan kemampuan memproses informasi siswa dalam pembelajaran sejarah dengan penggunaan teknik time 
token Arends pada metode debat. Hal tersebut terlihat dari setiap tindakan penelitian, siswa mengalami peningkatan dalam kemampuan memproses informasi. Setelah tiga kali tindakan menggunakan teknik time token Arends pada metode debat, siswaterlihatantusiasdalammencari informasi dan mendiskusikannya dengan teman sekelompoknya. Kemudian, pada lembar observasi siswa dalam penilaian individu menunjukan adanya peningkatan dari setiap tindakannya. Peningkatan kemampuan memproses informasi siswa dalam pembelajaran sejarah dari siklus I sampai siklus III adalah 29,3\%. Proses pembelajaran sejarah di kelas XI MIPA 1 setelah diterapkannya penggunaan teknik time token Arends pada metode debat di kelas siswa menjadi tidak mudah lupa karena siswalebih memahamidan mengerti tujuan pembelajaran dalam permbelajaran sejarah pada setiap tindakannya. Maka dengan penggunaan teknik time token Arends pada metode debat yang menarik perhatian siswa dapat mendorong siswa untuk berkontribusi dalam proses belajar mengajar. Teknik time token Arends pada metode debat ini menjadi jembatan untuk siswa agar lebih mudah untuk memahami materi dan membuat siswa aktif dalam proses pembelajaran baik individu maupun kelompok dan menjadikan suasana pembelajaran sejarah menjadi lebih hidup dan menyenangkan. Dengan demikian, terdapat pengaruh yang signifikan dalam penggunaan teknik time token Arends pada metode debat untuk meningkatkan kemampuan memproses informasi siswa dalam pembelajaran Sejarah.

\section{DAFTAR PUSTAKA}

Arends, R.I. (2008). Learning to Teach: Belajar untuk Mengajar. (Edisi Ketujuh/Buku Dua). Yogyakarta: Pustaka Pelajar.

Arikunto, S., Shardjono \& Supardi. (2009). Penelitian Tindakan Kelas. Jakarta: Bumi Aksara.

Garvey, B \& Mary K. (2015). Model-Model Pembelajaran Sejarah di Sekolah Menengah. Yogyakarta: Ombak.

Hasan, S. H. (1997). Pendidikan Ilmu Sosial. Jakarta: Departemen Pendidikan dan Kebudayaan Direktorat Jendral Pendidikan Tinggi.

Mulyasa, E. (2009). Menjadi Guru Profesional: Menciptakan Pembelajaran Kreatif dan Menyenangkan. Bandung: Remaja Rosdakarya.

Rusman. (2015). Pembelajaran Tematik Terpadu: TeoriPeraktikdan Penilaian. Jakarta: Raja Grafindo Persada.

Sukardi, H. M. (2013). Metode Penelitian Tindakan Kelas, Implementasi dan Pengembangannya. Jakarta: Bumi Aksara.

Wiriaatmadja, R.(2012).Metode Penelitian Tindakan Kelas untuk Meningkatkan Kinerja Guru dan Dosen. Bandung: Remaja Rosdakarya.

\section{Jurnal}

Purnomo, C. (2014). Meningkatkan Studi Lanjut melalui Metode Debat Aktif dalam Layanan Bimbingan Konseling. Jurnal Pendidikan Penabur, (22), 1-11. 